\title{
Blood Glucose Influence on Cholesterol and Blood Pressure of Patients with Type II Diabetes Mellitus
}

\author{
Idola Perdana Sulistyoning Suharto*, Satria Eureka Nurseskasatmata \\ Faculty of Health Sciences, Kadiri University, Kediri, Indonesia \\ *idolaperdana@unik-kediri.ac.id
}

\begin{abstract}
Diabetes is a metabolic disease that has signs of hyperglycemia due to lack of insulin secretion, insulin action, or both. The purpose of this study was to determine the blood glucose influence on cholesterol and blood pressure of patients with type 2 diabetes mellitus. This research was correlative analytic study. The sample consisted of 24 respondents. Data analyzed using Spearman's rho. Spearman's rho test results on blood glucose and cholesterol are a significance value of 0.001 and a correlation coefficient of 0.619. This can be interpreted that there is an influence between blood glucose and cholesterol with a strong relationship. Spearman's rho test results on blood glucose and blood pressure are a significance value of 0.000 and a correlation coefficient of 0.798 . This can be interpreted that there is an influence between blood glucose and blood pressure with a strong relationship. The conclusion of this study is that there is an influence between blood glucose with cholesterol and blood pressure in patients with type 2 diabetes mellitus.
\end{abstract}

Keywords : Blood Glucose, Blood Pressure, Cholesterol 


\section{STRADA Jurnal Ilmiah Kesehatan}

DOI: $10.30994 /$ sjik.v9i2.255

ISSN: 2252-3847 (print); 2614-350X (online)

Vol.9 No.2 November 2020 Page.629-634

\section{BACKGROUND}

Diabetes is a metabolic disease that has signs of hyperglycemia due to lack of insulin secretion, insulin action, or both (American Diabetes Association, 2014). Diabetes mellitus (DM) is a general term for a set of metabolic disorders with the main characteristic is being chronic hyperglycemia. This condition is the result of an impaired insulin secretion or an impaired insulin efficacy or, most often, both (Petersmann et al., 2018). Type 2 diabetes mellitus is a progressive metabolic disease characterized by insulin resistance $(\mathrm{Yu}$ et al., 2016).

The incidence of type 2 diabetes mellitus has increased every year. The International Diabetes Federation has estimated that patients with diabetes mellitus reach 0.382 billion worldwide in 2013 and is likely to reach 0.552 billion in 2030, 60\% of patients are expected to be in Asia (Yu et al., 2016). Based on World Health Organization (WHO) reports the incidence of DM in Indonesia, DM will continue to increase from 8.4 million in 2000 and to 21.3 million in 2030. The data states that Indonesia ranks fourth in the world after India (79.4 million), China (42.3 million) and the United States (30.3 million). DM patients in Indonesia who have not been diagnosed are estimated at $50 \%$, only two-thirds undergo received non-pharmacological or pharmacological treatment. According to the WHO, DM sufferers in the world is estimated to increase from 171 million people (18.1\%) in 2000 to 366 million people (4.4\%) in 2030 (Putri, Karimi, \& Nugraha, 2014).

One of the provinces in Indonesia that needs attention is East Java, which has a prevalence of $2.5 \%$ of the total population. In addition, Riset Kesehatan Dasar (Riskesdas) data also shows that there was an increase in prevalence in East Java from 2007 which was $1.3 \%$ to 2.5\% in 2013 (Tritisar, Handayani, Ariestiningsih, \& Kusumastuty, 2017). Based on a report in the City of Kediri Health Service the prevalence of people with diabetes mellitus was 7789 cases in 2015 (Suharto, Lutfi, \& Rahayu, 2019).

Cholesterol is the main sterol that is synthesized by animals and humans, which is an important component of cell membranes, and a precursor of steroid hormones, vitamin D, and bile acids (Simpson, 2012). Cholesterol is an important component of cell membranes and plays a role in controlling its physical properties, which in turn affects the function of plasma membrane proteins and the formation and fusion of vesicles. All cells, as well as pancreatic $\beta$ cells, are able to synthesize cholesterol, through the mevalonate pathway. Some observations indicate cellular cholesterol accumulation may cause dysfunction of pancreatic $\beta$ cells. Patients with type 2 diabetes-related lipid grouping of cholesterol and fatty acid in pancreatic $\beta$ cells and may contribute to the degeneration of pancreatic islets (Perego et al., 2019).

Hyperglycemia causes an increase in blood cholesterol. This condition can occur due to an increase in blood glucose levels which causes low glucose levels in cells, which results in a decrease in glucose oxidation and a decrease in energy production. Decreased energy produced by cells will cause an increase in lipid catabolism. Increased lipid catabolism causes an increase in cholesterol synthesis (Yuiwarti, Saraswati, \& Kusdiyantini, 2018).

Blood pressure is one of the most commonly measured types of clinical parameters and blood pressure values are the main determinants of therapeutic decisions (Magder, 2018). Diabetes plays an important role in the occurrence of microvascular complications by eliminating endothelial function. Endothelial dysfunction is associated with organ damage and clinical prognosis in patients with hypertension. Endothelial cells are also an important player in the development, maintenance, and remodeling of blood vessel tissue (Zhang, Xu, Thakur, \& Omondi, 2018). Patients with Type 2 Diabetes Mellitus have a high prevalence of non-alcoholic fatty liver disease (NAFL). NAFLD is independently 


\section{STRADA Jurnal Ilmiah Kesehatan}

DOI: $10.30994 /$ sjik.v9i2.255

ISSN: 2252-3847 (print); 2614-350X (online)

Vol.9 No.2 November 2020 Page.629-634

related with an increased risk of incident hypertension (Lonardo, Nascimbeni, Mantovani, \& Targher, 2017).

Almost $50 \%$ of patients with diabetes have hypertension. The mechanism of hypertension after diabetes include increased fluid volume of blood circulation by high blood glucose levels and improved response sympathetic vasoconstrictor hypertension due to insulin resistance (Tatsumi et al., 2019).

Based on the above, researchers are interested to learn about blood glucose influence on cholesterol and blood pressure of patients with type 2 diabetes mellitus.

The purpose of this study was to determine the blood glucose influence on cholesterol and blood pressure of patients with type 2 diabetes mellitus.

\section{METHODS}

This research was conducted in Tamanan, Kediri City. The study began in Maret 2020. This study was a correlative analytic study. The sample in this study is people with diabetes mellitus in Kelurahan Tamanan, Kediri City with a total of 24 respondents.

Data collection procedure begins with approaching and giving an explanation to prospective respondents about the purpose, objectives and benefits of the research to be carried out, then asks the respondent to fill out an approval letter and sign the consent form to become a respondent. The next measured levels of blood glucose, cholesterol, and blood pressure. After all data has been collected, data processing and analysis are carried out. The research data was tested with Spearman's rho.

\section{RESULTS}

Blood glucose levels of patients with type 2 diabetes mellitus

Tabel 1. Blood glucose levels of patients with type 2 diabetes mellitus

\begin{tabular}{cccc}
\hline No & Blood glucose levels & f & $\%$ \\
\hline 1 & Hyperglycemia & 21 & 87,5 \\
2 & Normal & 3 & 12,5 \\
\hline & Total & 24 & 100 \\
\hline
\end{tabular}

According to the table 1 we can see that almost all respondents $(87,5 \%)$ hyperglycemia.

Cholesterol level of patients with type 2 diabetes mellitus

Tabel 2. Cholesterol level of patients with type 2 diabetes mellitus

\begin{tabular}{cccc}
\hline No & Blood glucose levels & $\mathrm{f}$ & $\%$ \\
\hline 1 & Hypercholesterolemia & 21 & 87,5 \\
2 & Normal & 3 & 12,5 \\
\hline & Total & 24 & 100 \\
\hline
\end{tabular}

According to the table 2 we can see that almost all respondents $(87,5 \%)$ hypercholesterolemia.

Blood pressure of patients with type 2 diabetes mellitus

Tabel 3. Blood pressure of patients with type 2 diabetes mellitus

\begin{tabular}{cccc}
\hline No & Blood glucose levels & F & $\%$ \\
\hline 1 & Hypertension & 22 & 91,7 \\
2 & Normal & 2 & 8,3 \\
\hline & Total & 24 & 100 \\
\hline
\end{tabular}




\section{STRADA Jurnal Ilmiah Kesehatan}

DOI: $10.30994 /$ sjik.v9i2.255

ISSN: 2252-3847 (print); 2614-350X (online)

Vol.9 No.2 November 2020 Page.629-634

According to the table 3 we can see that almost all respondents $(91,7 \%)$ hypertension.

Influence of blood glucose levels on cholesterol of patients with type 2 diabetes mellitus Tabel 4. Influence of blood glucose levels on cholesterol of patients with type 2 diabetes mellitus

\begin{tabular}{lc}
\hline \multicolumn{2}{c}{ Spearman's rho test beetwen blood glucose and cholesterol } \\
\hline Correlation Coeffisien & 0,619 \\
Sig. (2 Tailed) & 0,001 \\
N & 24 \\
\hline
\end{tabular}

Based on table 4 it can be seen that the significance value ( $\mathrm{p}$ value) is 0,001 . P value $<\alpha$ means that there is an influence between blood glucose level and cholesterol level. The correlation coefficient of this test is 0,619 which means that blood glucose and cholesterol levels have a strong relationship.

Influence of blood glucose levels on blood pressure of patients with type 2 diabetes mellitus

Tabel 5. Influence of blood glucose levels on blood pressure of patients with type 2 diabetes mellitus

\begin{tabular}{lc}
\hline \multicolumn{2}{c}{ Spearman's rho test beetwen blood glucose and cholesterol } \\
\hline Correlation Coeffisien & 0,798 \\
Sig. (2 Tailed) & 0,000 \\
N & 24 \\
\hline
\end{tabular}

Based on table 5 it can be seen that the significance value ( $\mathrm{p}$ value) is 0,000 . P value $<\alpha$ means that there is an influence between blood glucose level and blood pressure level. The correlation coefficient of this test is 0,798 which means that blood glucose and blood pressure levels have a strong relationship.

\section{DISCUSSION}

This research was conducted on 24 respondents with type 2 diabetes mellitus. Observations were made with respondents by checking blood glucose, cholesterol, and blood pressure levels.

According to the table 1 we can see that almost all respondents $(87,5 \%)$ hyperglycemia. Hyperglycemia is the main sign of diabetes (Chang \& Yang, 2016). Based on table 2 we can see that almost all respondents $(87,5 \%)$ hypercholesterolemia. Hypercholesterolemia was defined by the presence of high plasma cholesterol levels, normal plasma triglycerides, a consequence of the increase in cholesterol and apolipoprotein B (apoB) rich lipoproteins, the so-called low-density lipoprotein (LDL) (Martinez-hervas \& Ascaso, 2018). Based on table 4 it can be seen that the significance value ( $\mathrm{p}$ value) is 0,001 . $\mathrm{P}$ value $<\alpha$ means that there is an influence between blood glucose level and cholesterol level. The correlation coefficient of this test is 0,619 which means that blood glucose and cholesterol levels have a strong relationship.

Type 2 diabetes mellitus is defined as a metabolic disorder and is usually due to excess calorie intake compared to energy expenditure. Diabetes mellitus type 2 is one of the most common chronic diseases worldwide and one of the major public health challenges of the 21 st century. Chronic hyperglycemia is associated with long-term damage, dysfunction, and failure of different organs, such as the eyes, kidneys, nerves, 


\section{STRADA Jurnal Ilmiah Kesehatan}

DOI: $10.30994 /$ sjik.v9i2.255

ISSN: 2252-3847 (print); 2614-350X (online)

Vol.9 No.2 November 2020 Page.629-634

heart, and blood vessels which results in increased levels of morbidity and mortality. (Zhao, Xu, Wu, \& Yi, 2015).

The condition of hyperglycemia in type 2 diabetes mellitus occurs because of a high concentration of glucose in the blood. High glucose levels in the blood caused by the glucose can not enter the cells, so the cells lack of raw materials to produce energy. Lack of energy production is forcing the body to perform lipid catabolism that increase the release of cholesterol into the blood. Therefore, when the measurement of cholesterol levels, then the result is blood cholesterol levels will rise (Yuiwarti et al., 2018). Therefore blood glucose levels affect blood cholesterol levels.

According to the table 3 we can see that almost all respondents $(91,7 \%)$ hypertension. Based on table 5 it can be seen that the significance value ( $\mathrm{p}$ value) is 0,000 . P value $<\alpha$ means that there is an influence between blood glucose level and blood pressure level. The correlation coefficient of this test is 0,798 which means that blood glucose and blood pressure levels have a strong relationship.

Blood pressure rises with age and the risk of hypertension in old age. Hypertension results from complex interactions between genetic, metabolic and behavioral factors such as body weight, salt intake, physical activity, alcohol intake, blood sugar, and many other factors (Poorolajal, Farbakhsh, Mahjub, Bidarafsh, \& Babaee, 2015).

In type 2 diabetes mellitus, insulin resistance occurs. Insulin resistance can trigger hypertension by activating the sympathetic nervous system and interfering with the suppression of the renin-angiotensin system (RAS), thereby increasing sodium retention. Diabetes causes increased vascular activity and proliferation of vascular smooth muscle cells, which is thought to play an important role in the development of hypertension (Horr \& Nissen, 2016).

Patients with diabetes have a higher coronary atherosclerotic plaque. Hyperglycemia is one of the significant factors for coronary atherosclerotic plaques. Hyperglycemia alter vascular tissue at the molecular level by increasing oxidative stress and pro-inflammatory response and promote glycation end products (AGE), and activation of protein kinase $\mathrm{C}$ (PKC), which jointly promote the development of atherosclerosis and coronary atherosclerotic plaques (Zhou et al., 2018). This condition causes hypertension in patients with type 2 diabetes mellitus. Therefore blood glucose levels affect blood pressure.

\section{CONCLUSION}

The conclusion of this study is that there is an influence between blood glucose and blood pressure in patients with type 2 diabetes mellitus.

\section{REFERENCES}

American Diabetes Association. (2014). Diagnosis and Classi fi cation of Diabetes Mellitus. Diabetes Care, 37(January), 81-90. https://doi.org/10.2337/dc14-S081

Chang, S., \& Yang, W. V. (2016). Hyperglycemia, Tumorigenesis, and Chronic Inflammation. Critical Reviews in Oncology / Hematology, (november), 1-35. https://doi.org/10.1016/j.critrevonc.2016.11.003

Horr, S., \& Nissen, S. (2016). Managing Hypertension in Type 2 Diabetes Mellitus. Best Practice \& Research Clinical Endocrinology \& Metabolism, 30(3). https://doi.org/10.1016/j.beem.2016.06.001

Lonardo, A., Nascimbeni, F., Mantovani, A., \& Targher, G. (2017). Review Hypertension , Diabetes , Atherosclerosis and NASH : Cause or Consequence ? Journal of Hepatology, xxx, 1-18. https://doi.org/10.1016/j.jhep.2017.09.021 


\section{STRADA Jurnal Ilmiah Kesehatan}

DOI: $10.30994 /$ sjik.v9i2.255

ISSN: 2252-3847 (print); 2614-350X (online)

Vol.9 No.2 November 2020 Page.629-634

Magder, S. (2018). The meaning of blood pressure. Critical Care, 22(257), 1-10. https://doi.org/https://doi.org/10.1186/s13054-018-2171-1

Martinez-hervas, S., \& Ascaso, J. F. (2018). Hypercholesterolemia. In Encyclopedia of Endocrine Disease (pp. 1-7). Elsevier Inc. https://doi.org/10.1016/B978-0-12801238-3.65340-0

Perego, C., Dalt, L. Da, Norata, G. D., Pirillo, A., Galli, A., \& Catapano, A. L. (2019). Cholesterol metabolism, pancreatic $\beta$-cell function and diabetes. BBA - Molecular Basis of Disease, 1865(9), 2149-2156. https://doi.org/10.1016/j.bbadis.2019.04.012

Petersmann, A., Nauck, M., Müller-wieland, D., Kerner, W., Müller, U. A., Landgraf, R., ... Heinemann, L. (2018). Definition, Classification and Diagnosis of Diabetes Mellitus. German Diabetes Association: Clinical Practice Guidelines, 126, 406-410. https://doi.org/10.1055/a-0584-6223

Poorolajal, J., Farbakhsh, F., Mahjub, H., Bidarafsh, A., \& Babaee, E. (2015). How Much Excess Body Weight, Blood Sugar, or Age can Double the Risk of Hypertension? Public Health, 133, 14-18. https://doi.org/10.1016/j.puhe.2015.10.014

Putri, L. K., Karimi, J., \& Nugraha, D. P. (2014). Profil Pengendalian Diabetes Melitus Tipe 2 Di Poliklinik Penyakit. JIK, 8(1), 18-24.

Simpson, W. (2012). Cholesterol ( blood, plasma , serum ). Association for Clinical Biochemistry, 1-5.

Suharto, I. P. S., Lutfi, E. I., \& Rahayu, M. D. (2019). PENGARUH PEMBERIAN JAHE (Zingiber officinale) TERHADAP GLUKOSA DARAH PASIEN DIABETES MELLITUS. Care, 8487(3), 76-83.

Tatsumi, Y., Morimoto, A., Asayama, K., Sonoda, N., Miyamatsu, N., Ohno, Y., ... Ohkubo, T. (2019). Fasting Blood Glucose Predicts Incidence of Hypertension Independent of HbA1c Levels and Insulin Resistance in Middle-Aged Japanese: The Saku Study. American Journal of Hypertension, 32(12), 1178-1185. https://doi.org/https://doi.org/10.1093/ajh/hpz123

Tritisar, K. P., Handayani, D., Ariestiningsih, A. D., \& Kusumastuty, I. (2017). Intake of the Food Sources of Antioxidants with Fasting Blood Glucose Levels in People with Type 2 DM in East Java. Majalah Kesehatan FKUB, 96-104.

Yu, H., Xie, L. F., Chen, K., Yang, G. Y., Xing, X. Y., Zhao, J. J., ... Chen, B. (2016). Initiating Characteristics of Early - onset Type 2 Diabetes Mellitus in Chinese Patients. Cinese Medical Journal, 129(7), 1-7. https://doi.org/10.4103/03666999.178959

Yuiwarti, E. Y. W., Saraswati, T. R., \& Kusdiyantini, E. (2018). Effect of VCO and Olive Oil on HDL, LDL , and Cholesterol Level of Hyperglycemic Rattus Rattus

Norvegicus. Journal of Physics, 1-6. https://doi.org/10.1088/17426596/1025/1/012064

Zhang, H., Xu, Q., Thakur, A., \& Omondi, M. (2018). Endothelial Dysfunction in Diabetes and Hypertension : Role of MicroRNAs and Long Non-Coding RNAs. Life Sciences, 213(October), 258-268. https://doi.org/10.1016/j.lfs.2018.10.028

Zhao, Y., Xu, G., Wu, W., \& Yi, X. (2015). Type 2 Diabetes Mellitus- Disease, Diagnosis and Treatment. Journal of Diabetes and Metabolism, 6(5).

https://doi.org/10.4172/2155-6156.1000533

Zhou, H., Wang, X., Zhu, J., Fish, A. F., Kong, W., Li, F., ... Lou, Q. (2018). Relation of Carotid Artery Plaque to Coronary Heart Disease and Stroke in Chinese Patients : Does Hyperglycemia Status Matter? Authors. Thieme Experimental and Clinical Endocrinology \& Diabetes, 126(3), 134-140. https://doi.org/10.1055/s-0042-124420 